\title{
Preparation of Porous Poly(Lactic Acid)/Tricalcium Phosphate Composite Scaffolds for Tissue Engineering
}

\author{
Franco Leonardo Redondo ${ }^{1,2}$ (D), María Carolina Giaroli ${ }^{1,2}$ (D), Andrés Eduardo Ciolino ${ }^{3,4}$ (D), Mario \\ Daniel Ninago ${ }^{1,2 *}$ (D)
}

1 National University of Cuyo. Faculty of Applied Sciences to Industry, Bernardo de Irigoyen 375, San Rafael, (5600), Mendoza, Argentina

2 National Scientific and Technical Research Council (CONICET), Godoy Cruz 2290, Ciudad Autónoma de Buenos Aires, (C1425FQB), Buenos Aires, Argentina

3 Pilot Plant of Chemical Engineering, PLAPIQUI (UNS-CONICET), Camino “La Carrindanga” Km 7, (8000), Bahía Blanca, Buenos Aires, Argentina

4 Chemical Engineering Department, National University of the South (UNS), Av. Alem 1253, (8000), Bahía Blanca, Buenos Aires, Argentina

* Correspondence: mninago@fcai.uncu.edu.ar (M.D.N)

Scopus Author ID 34768787800

Received: 28.06.2021; Revised: 15.08.2021; Accepted: 19.08.2021; Published: 20.10.2021

\begin{abstract}
The development of bioactive and composite materials for tissue engineering applications is being investigated worldwide. Many approaches have been published by including combinations of resorbable polymers with hydroxyapatite (HA), tricalcium phosphate (TCP), bioactive glasses and glass-ceramics in different scaffolds architectures. Taking into account these antecedents, porous polylactic acid (PLA)/TCP composites were fabricated by employing dissolution-leaching technic from PLA/chloroform solution (10, 15, and $20 \mathrm{wt} \%$ of TCP). Composite scaffolds exhibited porosity values $\sim 1.3$ times higher when compared to PLA foams. Their bioactive response of the composite foams after immersion in a simulated body fluid (SBF) was studied by X-Ray Diffraction (XRD) and Fourier Transform Infrared Spectroscopy (FTIR-ATR). By XRD analysis, diffraction peaks attributed to hydroxyapatite deposition were observed; and by FTIR-ATR, new absorption bands corresponding to HA were detected. Regarding mechanical properties, an increasing tendency on elastic Young's modulus values was observed at higher TCP concentrations. These results envision the feasibility of using these composites as precursors for bone tissue materials engineering.
\end{abstract}

Keywords: polymer composites; polylactic acid; tricalcium phosphate; bioactivity assessment; tissue engineering.

(C) 2021 by the authors. This article is an open-access article distributed under the terms and conditions of the Creative Commons Attribution (CC BY) license (https://creativecommons.org/licenses/by/4.0/).

\section{Introduction}

Ceramic materials such as hydroxyapatite (HA), phosphates, and silicate glasses are known for their "bioactivity" properties. In recent years, specific compositions have been used to obtain hard and soft implants for tissue engineering [1-5]. The development of bioresorbable and bioactive composites for tissue engineering applications are being investigated worldwide, and many approaches have been published by including combinations of resorbable polymers (such as polylactic acid, PLA, and polyglycolide, PGA) with HA, tricalcium phosphate $\left(\mathrm{Ca}_{3}\left(\mathrm{PO}_{4}\right)_{2}\right.$, TCP) or bioactive glasses and glass-ceramics in different scaffold architectures [610]. In the most usual approach, HA, TCP, and bioactive glass particles or fibers are combined 
with bulk or porous polymeric biodegradable substrates either as fillers or in the coating form to produce the desired scaffolds [11,12].

HA particles exhibit a similar chemical composition and crystalline structure to living bone. Moreover, HA shows high osteoconductivity as well as bioresorbability in biological environments [13-15]. One of the main purposes for employing HA in synthesizing biodegradable polymeric scaffolds (such as those obtained with polylactides) is its ability to modify surface properties in the resulting porous foams, which are suitable for their use in bone tissue engineering [13,16-18]. The deposition of the HA layer on polymeric materials by using a simulated body fluid (SBF) solution is generated by the increase in the supersaturation of inorganic ions in the medium. On the other hand, TCP excels in terms of degradability and bioactivity (two important reasons for its frequent use in clinical applications), and it has attracted much interest since it has been postulated as a precursor of HA formation [19]. Consequently, it might be reasonable to use TCP as a $\mathrm{Ca}^{2+}$ ions-releasing source by supplying the desired $\mathrm{Ca}^{2+}$ ions when immersed in SBF and by promoting HA synthesis [20,21].

Polylactic acid, PLA, is a semi-crystalline biodegradable polymer that has excellent thermoplastic behavior and good processability. PLA has a glass transition temperature $\left(T_{g}\right)$ at around $55-65{ }^{\circ} \mathrm{C}$ and a melting temperature range $\left(T_{m}\right)$ between $168-172{ }^{\circ} \mathrm{C}$. In addition, it has a high strain strength and a high elastic modulus. Therefore, it is employed in several applications fields such as food packaging, containers, lamination films, tissue engineering and 3D printing filaments [22-25]. PLA is commonly used for medical implant device fabrication and the production of scaffolds employed in skeletal or bone tissue engineering because of its excellent biocompatibility, bioresorbability, and biodegradability properties. In addition, it is approved by the US Food and Drug Administration (FDA) for different biomedical and clinical applications $[11,26]$. Another reason for using this polyester is that its degradation products are oligomers that cells can metabolize [26]. These degradation products are not toxic and biocompatible and are easily removed by natural metabolic pathways [11,26-28].

By taking into account the above-mentioned facts, the purpose of this work is to develop a simple and effective method to produce bioactive foams by employing PLA and TCP as filler and as $\mathrm{Ca}^{2+}$ sources for HA deposition. The emphasis of this work is placed on the high biocompatibility of HA and the synergy of PLA and HA composites because they have already demonstrated great potential in tissue engineering applications, for example, in the healing of affected hard tissues such as bone and teeth [11,29]. In this sense, this work provides useful information regarding the mechanical behavior, through compression tests, of the foams obtained from PLA and different percentages of TCP as filler. From the results obtained in this paper, it is envisioned that the materials synthesized in this work could be considered an alternative for scaffolds in bone tissue engineering.

\section{Materials and Methods}

\subsection{Materials.}

Commercial and transparent polylactic acid (PLA, Createbot, Argentina) was used as received. Sodium Chloride $(\mathrm{NaCl})$ (Biopack, $\geq 99 \%$, Argentina) and tricalcium phosphate $\left(\mathrm{Ca}_{3}\left(\mathrm{PO}_{4}\right)_{2}\right.$, TCP, Carlo Erba Reagents, Analytical grade, France) were used as porogen and filler precursors, respectively. Chloroform (Sintorgan, Argentina) was used as a solvent. For bioactivity assays, simulated body fluid (SBF) was prepared according to Kokubo and Takadama [30]. For this purpose, the SBF solution was prepared from the dissolution of the 
following salts: $\mathrm{NaCl}, \mathrm{NaHCO}_{3}, \mathrm{KCl}, \mathrm{K}_{2} \mathrm{HPO}_{4} .3 \mathrm{H}_{2} \mathrm{O}, \mathrm{MgCl}_{2} .6 \mathrm{H}_{2} \mathrm{O}, \mathrm{CaCl}_{2}, \mathrm{NaSO}_{4}$; and Tris $\left(\mathrm{NH}_{2} \mathrm{C}\left(\mathrm{CH}_{2} \mathrm{OH}\right)_{3}\right)$ in distilled water, at $37^{\circ} \mathrm{C}$ and $\mathrm{pH}=7.3$ - 7.4.

\subsection{PLA and TCP characterization.}

Fourier Transform Infrared Spectroscopy (FTIR-ATR). PLA and TCP spectra were registered on a Nicolet ${ }^{\circledR}$ iS5 spectrometer, equipped with an Attenuated Total Reflectance accessory (iD7-ATR). Samples were recorded at $4 \mathrm{~cm}^{-1}$ resolution, over the 3,500-550 $\mathrm{cm}^{-1}$ range, by using an accumulation of 16 scans. A Zinc Selenide $(\mathrm{ZnSe})$ internal reflection crystal was used for ATR measurements.

X-Ray Diffraction (XRD). Crystal structure identification of PLA and TCP were determined by XRD. Patterns were obtained in an X-ray diffractometer Philips PW1710 (Philips, Holland), provided with a tube, a copper anode, and a detector operating at $45 \mathrm{kV}$ and $30 \mathrm{~mA}$ within $2 \theta$ from 5 to $60^{\circ}$.

Differential Scanning Calorimetry (DSC). Thermal transitions of commercial PLA were studied in a TA-Instruments Calorimeter. Samples $(\cong 10 \mathrm{mg})$ were measured under a nitrogen atmosphere, with a flow of $50 \mathrm{~mL} \mathrm{~min}^{-1}$. First heating was performed from -90 to 210 ${ }^{\circ} \mathrm{C}$ at $10{ }^{\circ} \mathrm{C} \mathrm{min}^{-1}$. Then, samples were kept at $210{ }^{\circ} \mathrm{C}$ for $5 \mathrm{~min}$ in order to avoid the influence of the previous thermal history. After cooling at $10{ }^{\circ} \mathrm{C} \mathrm{min}^{-1}$, they were heated again from -90 to $210{ }^{\circ} \mathrm{C}$ at $10{ }^{\circ} \mathrm{C} \mathrm{min}{ }^{-1}$. From this second heating process, glass-transition temperature $\left(T_{g}\right)$ and melting temperature $\left(T_{m}\right)$ of PLA were determined.

Thermogravimetric Analysis (TGA). The thermal stabilities of PLA and TCP were analyzed by TGA by using a Discovery TA Instruments TGA5500 balance. Tests were carried out under a nitrogen atmosphere, with a flow of $25 \mathrm{~mL} \mathrm{~min}^{-1}$ and $2{ }^{\circ} \mathrm{C} \mathrm{min}{ }^{-1}$ heating rate, in the $50-700{ }^{\circ} \mathrm{C}$ range. Mass loss vs. heating temperature curves was registered.

Laser Diffraction (LD). The particle-size distribution of TCP was determined using a Horiba Partica LA-950 Laser Diffraction Particle Size Distribution Analyzer (Kyoto, Japan).

Scanning Electron Microscopy (SEM). TCP particles were analyzed by SEM, by using an LEO 40XVP scanning electron microscope operated at $10 \mathrm{kV}$. To perform this study, samples were dispersed over $3 \mathrm{M}^{\circledR}$ aluminum conductive tape by using airflow and coated with gold in a sputter coater SPI. From this analysis, the topographical characteristics of particles were obtained from secondary electron signals.

\subsection{Composite scaffolds.}

PLA/TCP foams were obtained through a dissolution-leaching methodology by employing chloroform ( $20 \% \mathrm{w} / \mathrm{v})$ as solvent. PLA solution was transferred to circular molds (40 mm diameter and $5 \mathrm{~mm}$ thickness). In these molds, different amounts of TCP $(10,15$, and $20 \%$ wt related to PLA mass) and $\mathrm{NaCl}$ crystals (in a $\mathrm{NaCl} /$ polyester ratio of 9:1 wt/wt with an average size of $255 \pm 35 \mu \mathrm{m}$ ) were added by following the methodology previously reported by Ninago et al. [31]. After 1 day of chloroform evaporation at room temperature, the samples were subjected to vacuum $\left(30{ }^{\circ} \mathrm{C}\right)$ for 4 hours to remove the remaining solvent. Then, they were washed by immersion in distilled water for 36 hours at room temperature, renewing the washing water every 6 hours. The resulting materials were stored in a desiccator until use. Composite porous foams were named $\mathrm{F}_{\mathrm{x}}$, where $\mathrm{x}$ denotes different TCP wt $\%(10,15$, and 20 $\%)$. 
In-vitro assessments. Bioactivity tests were carried out by soaking the foams in SBF for 7 and 14 days at $37^{\circ} \mathrm{C}$, replacing the SBF solution every 3 days, and following the protocol reported in the literature [30,32]. After soaking, specimens were gently washed with distilled water and dried in a desiccator up to constant weight. The resulting samples were named as $\mathrm{F}_{\mathrm{x}-}$ $y$, where $\mathrm{x}$ denotes different TCP wt\%; and y denotes the incubation time into SBF solution (7 and 14 days).

\subsection{Composite scaffolds characterization.}

Porosity of samples was calculated using the Equation (1) proposed in the literature $[16,33]$ :

$$
P=\left(1-\rho_{a p} / \rho_{P o l}\right) \times 100 \%
$$

where $P$ is the porosity of the sample, $\rho_{a p}$ is the apparent density of the foam, and $\rho_{P o l}$ is the density of the PLA. A reference value of $1.24 \mathrm{~g} \mathrm{~cm}^{-3}$ was used [25].

Thermal stability and crystal structure identification of samples after incubation in SBF solution were studied by TGA and XRD analysis by employing the aforementioned equipment. TGA curves were used to calculate the percentage of remaining residue after 7 and 14 days of immersion in SBF, while XRD tests were used to evaluate the presence of HA particles on foams.

Compression Test. Measurement of compressive strength was evaluated with a Texture Analyzer model TA-XT2i (Stable Micro Systems, UK), equipped with a $25 \mathrm{~kg}$ load cell. Mechanical properties of neat PLA foams and their composites were determined in dry and wet conditions. For wet conditions, samples were first immersed in SBF for 24 hours. The excess of liquid was removed with a paper filter just before applying the compressive force by following the methodology reported by Roohani-Esfahani et al. [34]. Samples were tested at room temperature, and a uniaxial compression force was applied up to $60 \%$ deformation using a cylindrical steel probe of $25 \mathrm{~mm}$ of diameter at $1 \mathrm{~mm} \mathrm{~s}^{-1}$. Automatic probe-foam contact detection was carried out with a force of $0.005 \mathrm{~N}$. Young's modulus was calculated for the first linear region with a non-zero slope, up to $10 \%$ stress, in the stress-strain curve.

Scanning Electron Microscopy (SEM-EDX). The fracture cross-section appearance of foams was analyzed by SEM, using a LEO 40XVP scanning electron microscope operated at $10 \mathrm{kV}$. In addition, an energy-dispersive X-ray detector (EDX, Model DX-4) with a UTW window and a standardless quantification method was used to analyze the elementary composition of samples. To perform this study, samples were coated with a thin layer of gold and carbon. From analysis, it was possible to visualize the cryo-fracture surface of the foams before and after being soaked in SBF solution. From this analysis, the $\mathrm{Ca} / \mathrm{P}$ ratio for each formulation was obtained.

\subsection{Statistical analysis.}

Any statistically significant difference in the pore size and porosity, as well as in the mechanical properties, were determined by statistical analysis of variance ANOVA one-way and using the comparison of means through the test of the least squared differences (LSD) of Fisher, using a significance level $\alpha=0.05$ and the StatGraphics Statistical Software. 


\section{Results and Discussion}

\subsection{PLA and TCP characterization.}

Figure 1a shows the FTIR-ATR spectra of PLA and TCP precursors. PLA exhibits the typical absorption bands of polyesters detected at 2,993 and 2,853 $\mathrm{cm}^{-1}$ (symmetric and asymmetric vibrations of the $\mathrm{C}-\mathrm{H}$ bond of the $\mathrm{CH}_{3}$ groups); 1,750 and $1,180 \mathrm{~cm}^{-1}(\mathrm{C}=\mathrm{O}$ and $\mathrm{C}$ O-C stretching peaks, respectively). The band at $1,450 \mathrm{~cm}^{-1}$ is attributed to $\mathrm{C}-\mathrm{H}$ stretching vibration in methyl groups, while bands at 1,381 and $1,362 \mathrm{~cm}^{-1}$ are attributed to symmetric and asymmetric vibrations of - $\mathrm{CH}$ - bending. The band at $1,080 \mathrm{~cm}^{-1}$ corresponds to carbonyl $\mathrm{C}=\mathrm{O}$ and $-\mathrm{OH}$ groups. Finally, two peaks at 868 and $752 \mathrm{~cm}^{-1}$ are assigned to the $\mathrm{C}-\mathrm{C}$ stretching vibration [23,35]. On the other hand, TCP shows typical absorption bands at 1,088, 561, and $600 \mathrm{~cm}^{-1}$ (bending out of the plane of the $\mathrm{PO}_{4}{ }^{3-}$ group); $1,037 \mathrm{~cm}^{-1}$ (asymmetric vibration of the $\mathrm{PO}_{4}{ }^{3-}$ group), and $962 \mathrm{~cm}^{-1}$ (asymmetric vibration of the $\mathrm{PO}_{4}{ }^{3-}$ group) [36-39]. Figure $1 \mathrm{~b}$ shows X-ray diffraction patterns of PLA and TCP. Three peaks associated with the orthorhombic semi-crystalline structure of PLA are detected at $2 \Theta \sim 16.8^{\circ}, 19.2^{\circ}$ and $22.4^{\circ}$ which correspond to the crystalline planes (110/200), (203) and (015), respectively [22]. On the other hand, five peaks associated with the structure of TCP are detected at $2 \Theta \sim 25.9^{\circ}$, $29.0^{\circ}, 31.8^{\circ}, 39.0^{\circ}$ and $46.7^{\circ}[40,41]$.
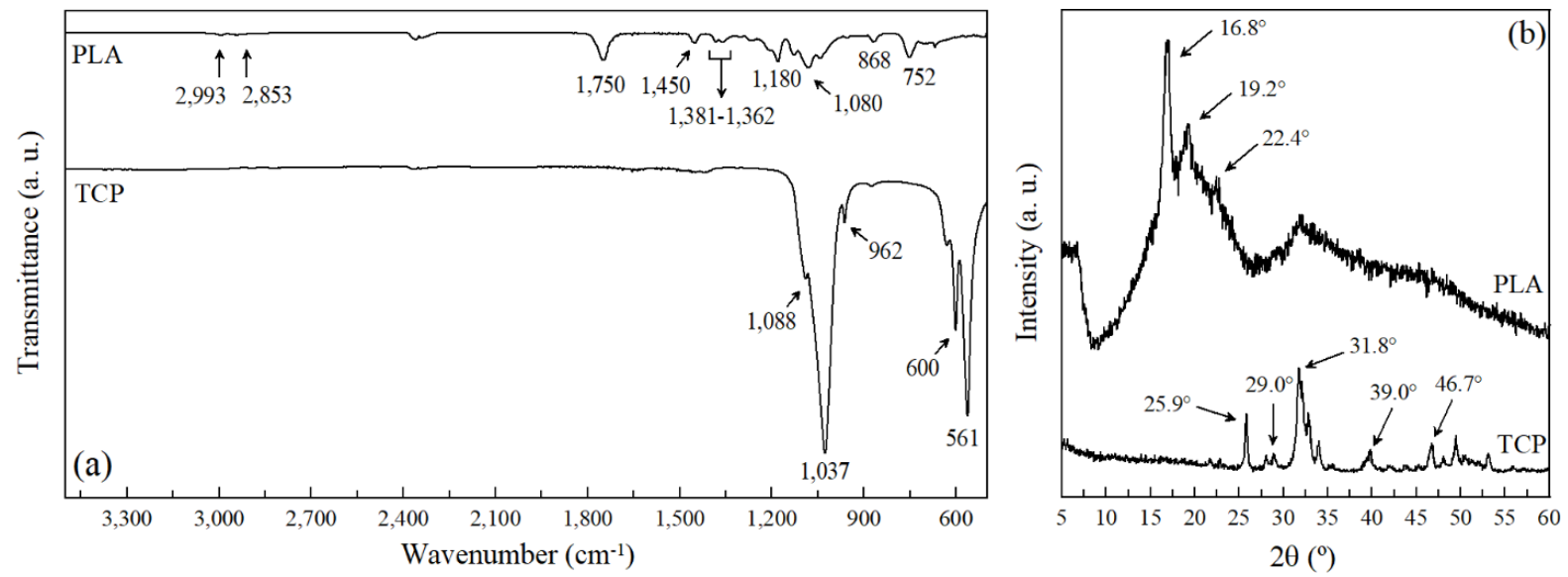

Figure 1. (a) FTIR-ATR spectra; (b) XRD diffractograms of polylactic acid, PLA, and tricalcium phosphate powder, TCP. Spectra and diffractograms are displaced in order to observe differences between them.

Figure 2 shows the thermal characterization by DSC analysis of PLA and TCP samples. From Figure $2 \mathrm{a}$, the $T_{g P L A}$ and $T_{m P L A}$ values obtained (close to 65 and $175{ }^{\circ} \mathrm{C}$, respectively) agree with those reported previously by literature for commercial PLA polyesters [24]. On the other hand, Figure $2 \mathrm{~b}$ displays mass loss percentage vs. temperature and the first derivative curve for PLA and TCP samples, respectively. PLA decomposition starts at $320{ }^{\circ} \mathrm{C}$, and is completed at $395{ }^{\circ} \mathrm{C}$ by reaching $98 \%$ wt mass loss. In this sense, Spiridon et al. reported a similar mass loss percentage when evaluating the properties of PLA bioplastics [42]. Regarding TCP, no decomposition event is observed unless in the studied range. These results agree with those values reported by Liu et al. during the evaluation of thermal stability of sintered TCP/poly-L-lactic acid scaffolds [43]. 

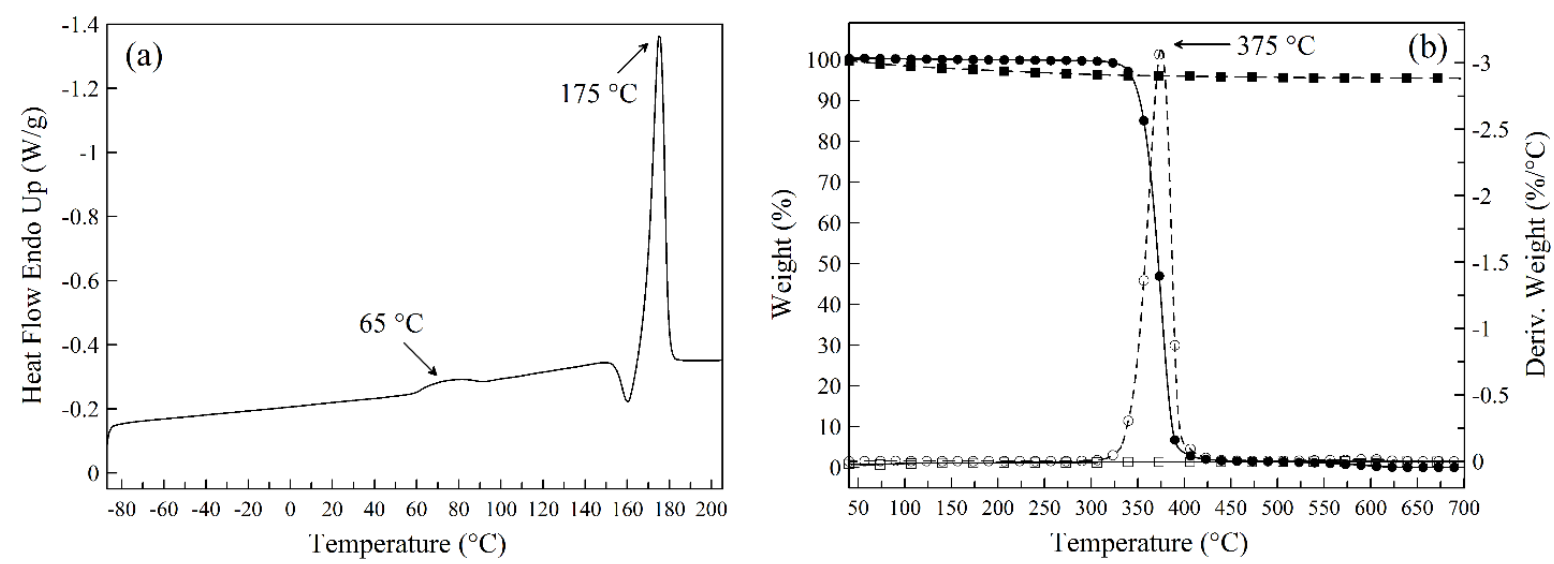

Figure 2. (a) DSC curve of commercial polylactic acid, PLA; (b) TGA and first derivative dW/dT curves of PLA and tricalcium phosphate powder, TCP. Symbols: $(\bullet)$ TGA curve of PLA; ( $\bullet$ ) TGA curve of TCP; (०) $\mathrm{dW} / \mathrm{dT}$ curve of PLA; $(\square) \mathrm{dW} / \mathrm{dT}$ curve of TCP.

The particle size distribution of TCP powder is shown in Figure 3a. From LD analysis, a unimodal distribution with an average size of $12.1 \mu \mathrm{m}$ and a smaller population shoulder (with an average size of $2.9 \mu \mathrm{m}$ ) were determined. SEM micrograph of TCP particles shows an irregular morphology, with non-spherical shapes, and the presence of aggregates with irregular borders (Figure 3b). These results are in accordance with those reported by Ginebra et al. and Nagase et al. $[44,45]$ and correspond to the typical appearance of TCP particles.

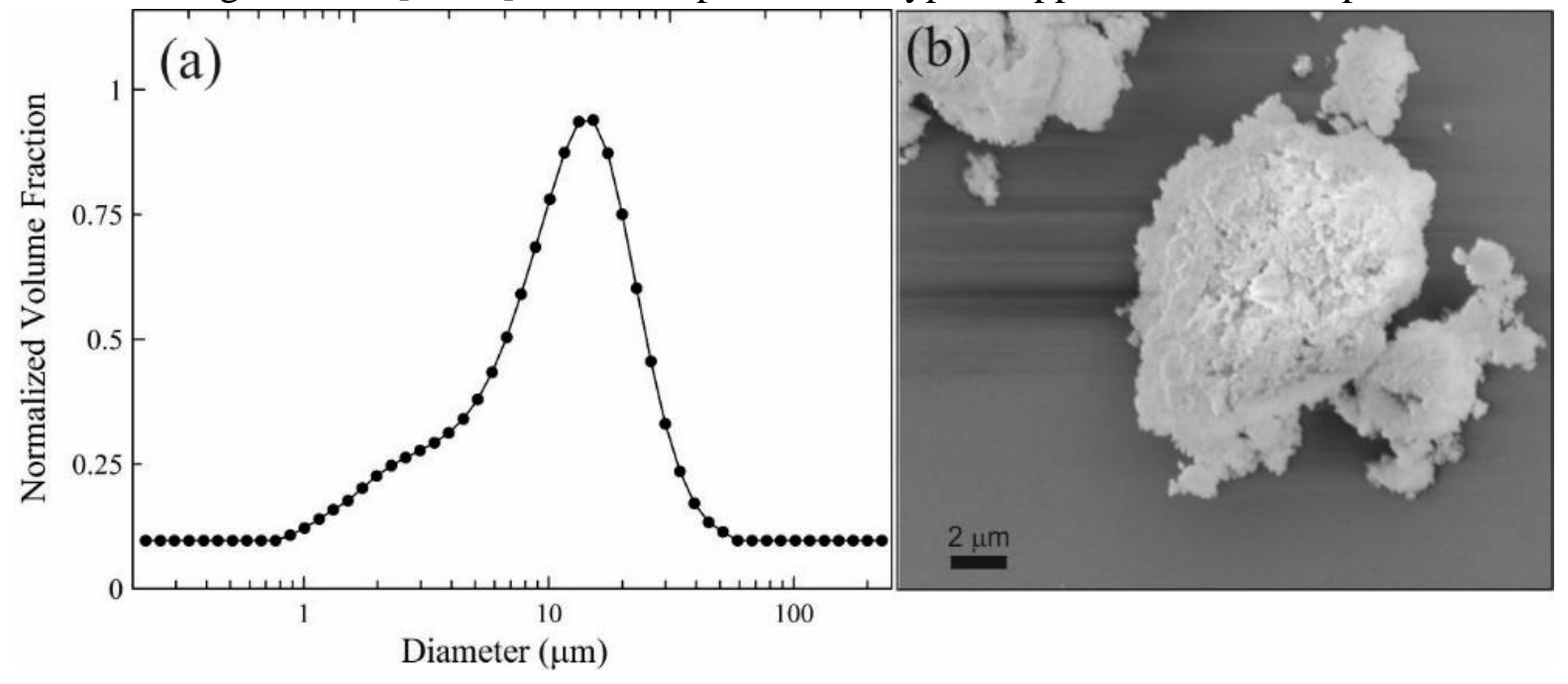

Figure 3. (a) Particle size distribution of TCP; (b) SEM micrograph of TCP particles.

\subsection{Composite scaffolds characterization.}

Table 1 shows porosity and pore size values obtained for PLA and PLA/TCP foams. According to statistical analysis, results show that PLA foams have porosity values close to 70 $\%$, whereas PLA/TCP reached mean porosity values between $86-88 \%$. These higher values show the utility of $\mathrm{NaCl}$ as a porogen agent and a synergistic effect when combined with TCP. In order to compare the mechanical properties of the foams obtained, Figure 4 shows the stressstrain curves for PLA and $\mathrm{F}_{20}$ samples, essayed at dry (PLA, $\mathrm{F}_{20-\mathrm{D}}$ ) and wet conditions (PLAW, $\mathrm{F}_{20-\mathrm{w}}$ ). All samples exhibit three compression regions: initial linear elasticity, long plateau, and densification regions, commonly observed for "cellular structures" or porous structures already described by literature [46]. As it can be seen, all curves exhibit linear regression extended to $30 \%$ deformation, and above this limit, the curve tends to rise upwards progressively. Upon 
release of the applied load, the decompression path does not retrace the compression one but gives rise to a hysteresis loop [47].

Table 1. Pore size and porosity values of foams.

\begin{tabular}{l|l|l} 
Samples & Pore size $(\boldsymbol{\mu m})$ & Porosity $(\%)$ \\
\hline PLA foam & $335.6 \pm 106.5$ & $69.5 \pm 9.5(\mathrm{a})$ \\
\hline F10 & n/d & $86.1 \pm 2.9(\mathrm{~b})$ \\
\hline F15 & n/d & $85.3 \pm 5.2(\mathrm{~b})$ \\
\hline F20 & $415.3 \pm 87.2$ & $88.0 \pm 1.4(\mathrm{~b})$
\end{tabular}

Values are the average of ten determinations \pm standard deviation. Different letters, (a) or (b), indicate significant differences $(\alpha<0.05)$ between samples.

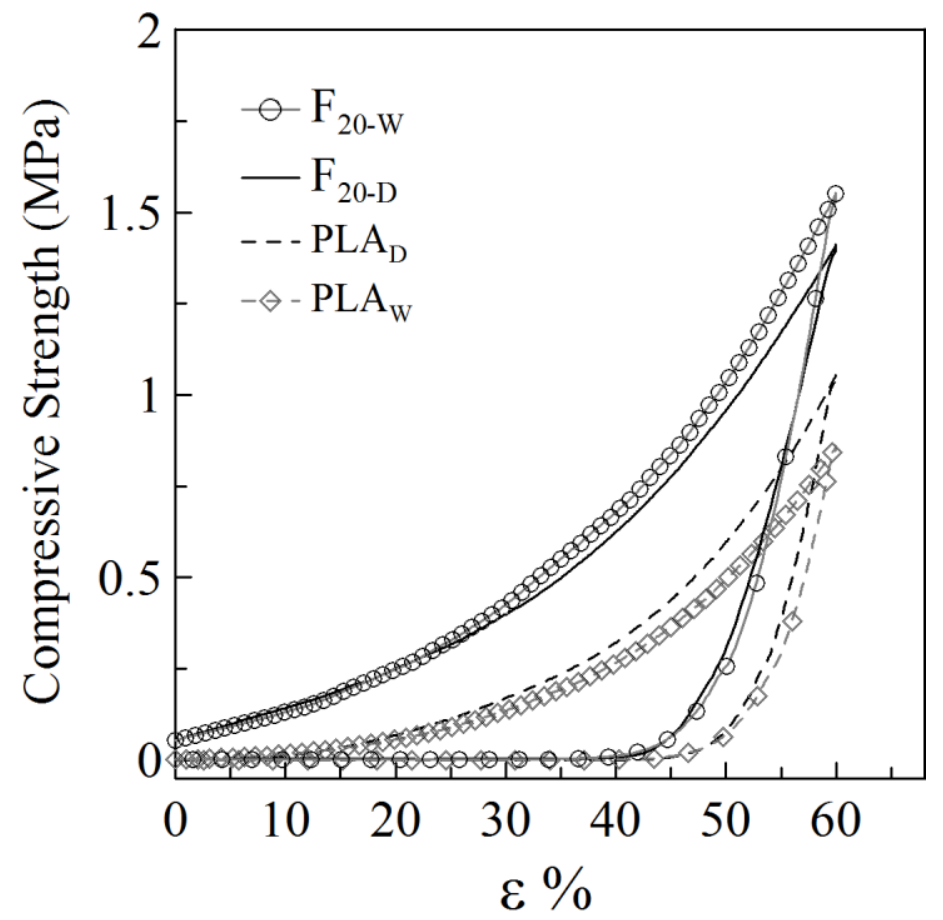

Figure 4. Stress-deformation curve of neat porous PLA foams and their composite with $20 \%$ wt filler in dry (D) and wet (W) conditions.

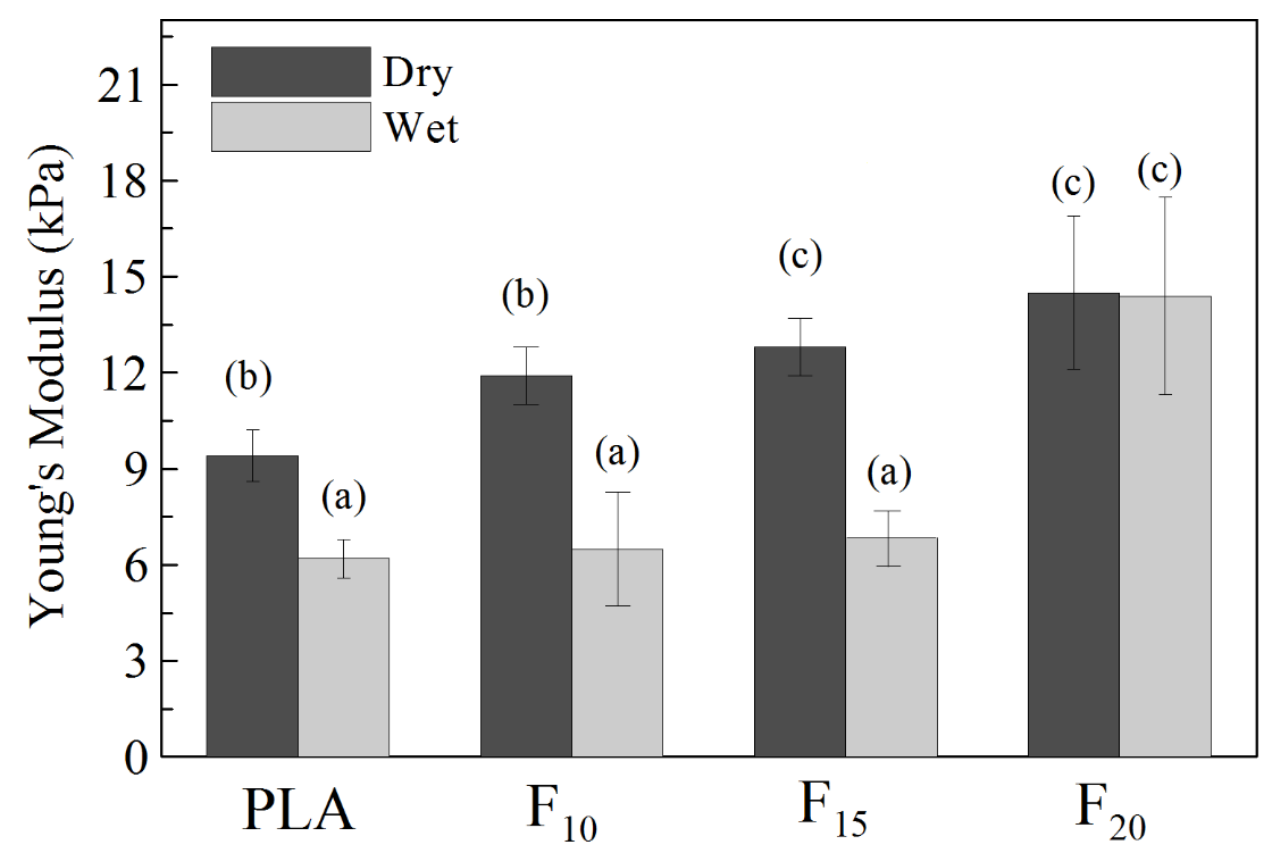

Figure 5. Compressive Young's Elastic modulus values of neat porous PLA foam and the porous foams with different $\%$ of TCP in dry and wet conditions. 
Maximum Young's modulus obtained in dry and wet conditions for all formulations is summarized in Figure 5. The values are the average of five determinations \pm standard deviation. Different letters on bars (a), (b), and (c) indicate significant differences $(\alpha<0.05)$ between dry and wet compressive conditions. As it can be seen, an increasing tendency on elastic Young's modulus values is observed at higher TCP concentration ( 2.2 times higher) when compared to samples unfilled at dry and wet conditions. However, no significant difference in the modulus strength is found when comparing 15 and $20 \%$ wt filler. In this context, Wu et al. reported similar behavior during the study of the mechanical compression performance of PLA composite reinforced with HA particles [48]. In this sense, incorporating TCP particles improved the elastic modulus. Furthermore, its linear increase when increasing TCP concentration might be explained (as a first approximation) by the rule of mixtures for elastic properties.

In-vitro assessments. Taking into account the results previously discussed, $\mathrm{F}_{20}$ sample was selected to evaluate its In-vitro response. Figure 6 shows the normalized FTIR-ATR spectra of $\mathrm{F}_{20}$ foam before and after immersion in SBF solution for 7 and 14 days, respectively. PLA absorption bands are distinguishable in all samples, and the absorption band at $1,040 \mathrm{~cm}^{-}$ ${ }^{1}$ (asymmetric vibration of the $\mathrm{PO}_{4}{ }^{3-}$ group) is attributed to the TCP filler. Regarding $\mathrm{F}_{20-7}$ and $\mathrm{F}_{20-14}$ foams, new vibration bands were detected at $3,183 \mathrm{~cm}^{-1}$ (stretching vibration attributed to the crystal water and surface adsorbed water molecules), $1,627 \mathrm{~cm}^{-1}$ (vibrations of $-\mathrm{COOH}$ group), and $1,550 \mathrm{~cm}^{-1}$ (vibration of $\mathrm{CO}_{3}{ }^{2-}$ group). These results are in good agreement with those described by Mohandes et al. [49]. In addition, a change in the intensity of absorption bands at 1,083 and $1,040 \mathrm{~cm}^{-1}$ is detected for different SBF immersion times. Mohandes et al. concluded that this change in frequency could be explained by taking into account the interaction of the carboxylic groups in the foams with new-formed HA nuclei $[39,49]$. The absorption band at $1,040 \mathrm{~cm}^{-1}$ increases its intensity when increasing time in SBF solution; for this reason, the development of a crystalline HA phase can be reasonably proposed [50].

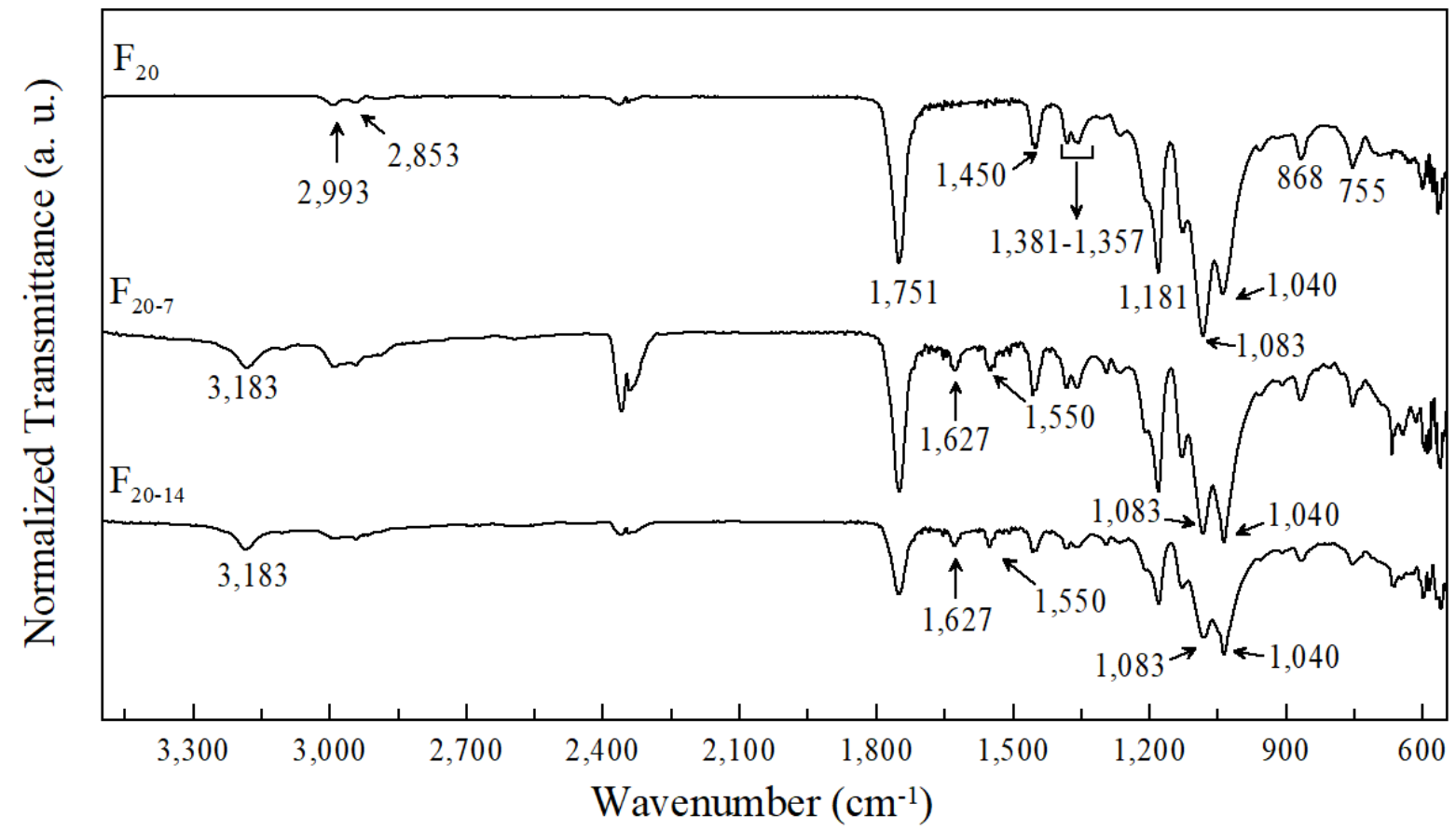

Figure 6. Normalized FTIR spectra of PLA foams with $20 \%$ wt of TCP filler before (F20) and after (F20-7 and F20-14) immersion in SBF solution. 
Figure 7 shows X-ray diffraction patterns of PLA foams with $20 \%$ wt of TCP filler $\left(\mathrm{F}_{20}\right)$ before and after being soaked in SBF solution for 14 days $\left(\mathrm{F}_{20-14}\right)$. The diffraction peaks associated with PLA and TCP were detected in both samples. XRD patterns of $\mathrm{F}_{20-14}$ exhibit diffraction peaks associated to HA phase [39]. Characteristic diffraction peaks of HA are detected at $2 \Theta$ values of $26.0^{\circ}, 31.9^{\circ}, 33.0^{\circ}, 34.1^{\circ}, 39.9^{\circ}, 46.8^{\circ}, 49.6^{\circ}$ and $53.3^{\circ}$, corresponding to the diffraction planes (002), (211), (300), (202), (310), (222), (213) and (004), respectively $[39,49]$. These results suggest that TCP particles are transformed into mineral HA during Invitro assessment [51]. In a similar analysis, Dorozhkin et al. stressed that chemical changes could occur in bioceramics materials when they are exposed to in vitro-conditions [20]. Thereby, in an acidic medium, it was found that TCP particles can be partially dissolved by causing the liberation of $\mathrm{Ca}^{+2}$ and $\mathrm{PO}_{4}^{-3}$ ions to the solution. Consequently, the increase of ions leads to the supersaturation of the biologic fluid by promoting the precipitation of biological HA nanocrystals. For example, Roether et al. reported that HA formed on PLA/Bioglass composite foams after 7 days of immersion in SBF [50]. In similar experiments, Zhang et al. reported that after 7 days of immersion in SBF, PLA/Bioglass composite foams fabricated using thermally induced phase separation (TIPS) developed HA on their surfaces [52]. According to these previous tests, and by considering the results discussed in this paper, TCP/PLA composite foams have the same HA forming ability as PLA/Bioglass composite foams already presented in the literature [52,53].

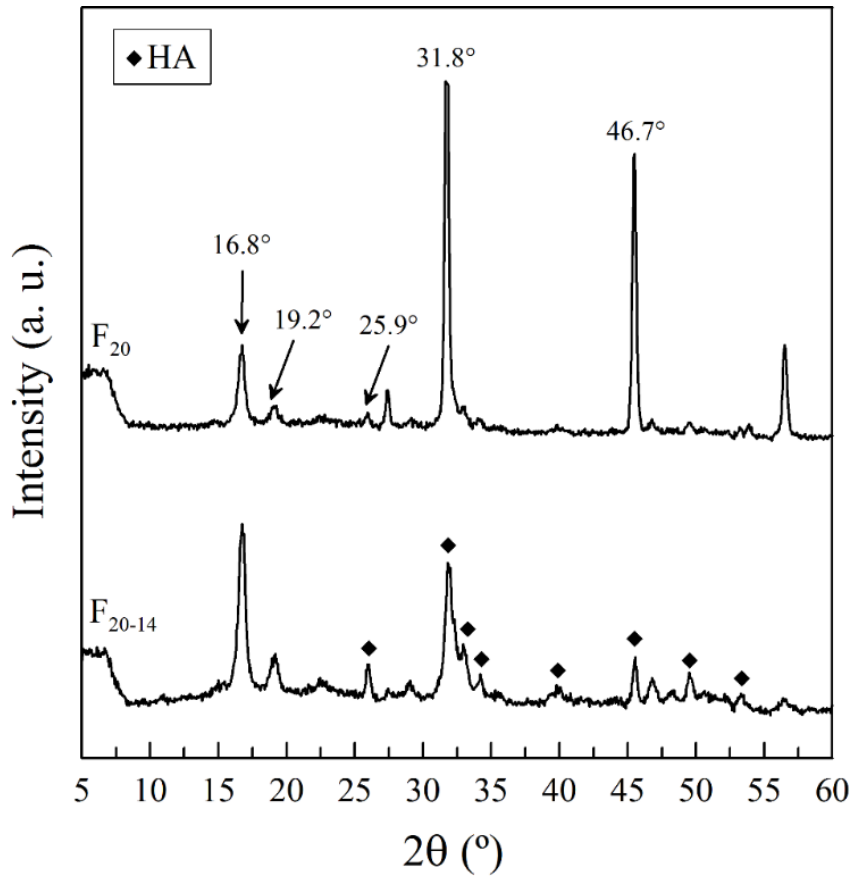

Figure 7. XRD spectra of porous PLA foam with $20 \%$ wt filler $\left(\mathrm{F}_{20}\right)$ before and after $\left(\mathrm{F}_{20-14}\right)$ immersion in SBF.

Figure 8 shows TGA and first derivative dW/dT curves of foams before $\left(\mathrm{F}_{20}\right)$ and after ( $\mathrm{F}_{20-14}$ In-vitro assessment. $\mathrm{F}_{20}$ and $\mathrm{F}_{20-14}$ foam composites show a weight-loss event between 50 to $200{ }^{\circ} \mathrm{C}$ attributed to removing absorbed water during the In-vitro assessment. It is important to highlight that mass loss events only could be attributed to degradation processes of polymeric chains since TCP powder is a stable material in the temperature range studied. Since TCP is stable even at high temperatures, no weight losses are detected. The decomposition of $\mathrm{F}_{20}$ started at $300{ }^{\circ} \mathrm{C}$, and it is completed at $350{ }^{\circ} \mathrm{C}$, reaching a $74 \%$ weight loss. The first derivative $\mathrm{dW} / \mathrm{dT}$ curve of $\mathrm{F}_{20}$ shows a single peak at $346{ }^{\circ} \mathrm{C}$. 

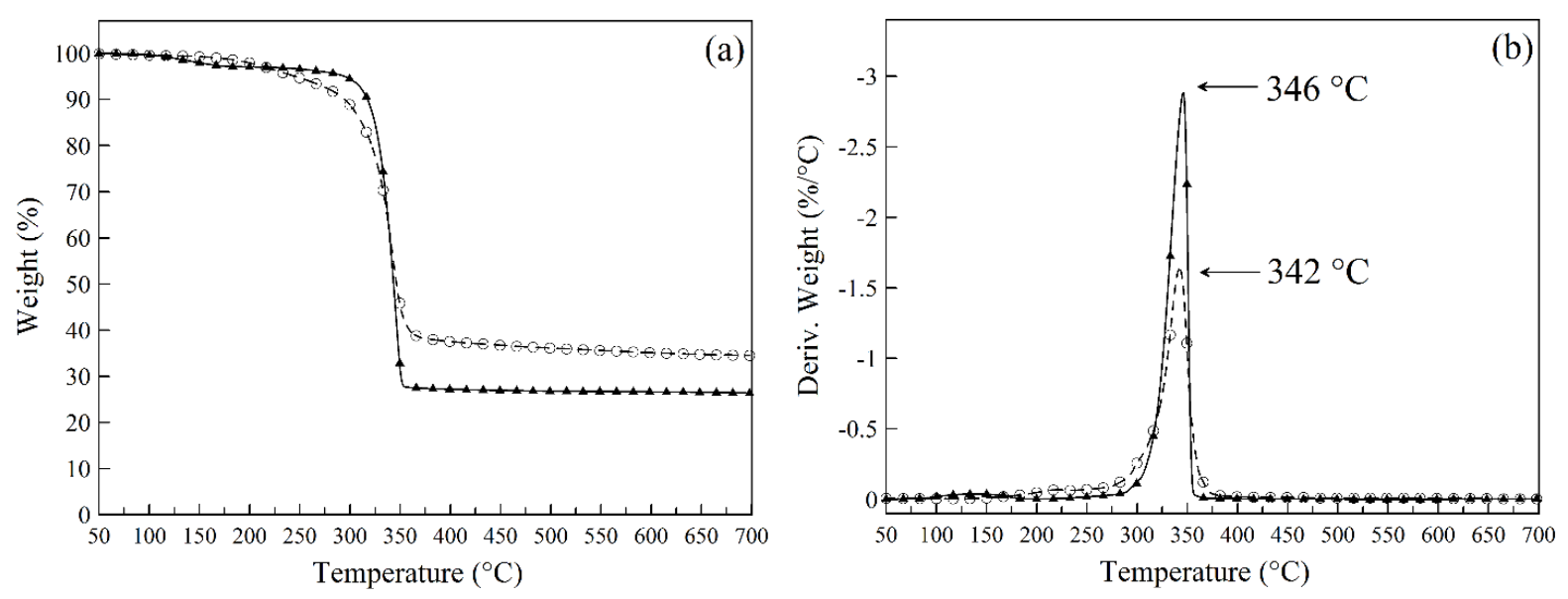

Figure 8. (a) TGA curves; (b) first derivative dW/dT curves of porous PLA foams with $20 \%$ wt filler before

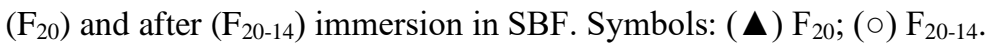

Regarding $\mathrm{F}_{20-14}$, the decomposition started at $260{ }^{\circ} \mathrm{C}$ and is completed at $365{ }^{\circ} \mathrm{C}$. In this case, $65 \%$ weight loss is recorded. The first derivative dW/dT curve of $\mathrm{F}_{20-14}$ shows a single peak at $342{ }^{\circ} \mathrm{C}$, closer to that value reported by Haaparanta et al. [54]. When comparing, the weight loss percentage for $\mathrm{F}_{20-14}$ is lower than $\mathrm{F}_{20}$ sample. These results could indicate that $\mathrm{F}_{20-14}$ foam has a higher content of HA precipitate itself. This behavior could be attributed to better transforming TCP into HA by a dissolution-precipitation mechanism, by producing a new inorganic phase when the sample is soaked in SBF solution for more days [51,55].

According to SEM-EDX analysis, Figure 9a shows the internal fractured surface of composite foam with $20 \% \mathrm{wt}$ filler $\left(\mathrm{F}_{20}\right)$ before being soaked in SBF solution. The micrograph reveals the presence of agglomerated and isolated micro-crystals corresponding to TCP particles. EDX pattern is also included in the figure in order to analyze the elementary composition of the foam, as well as the $\mathrm{Ca} / \mathrm{P}$ ratio. Figure $9 \mathrm{~b}$ shows the micrograph SEM of $\mathrm{F}_{20}$ sample after being immersed in SBF solution for 14 days $\left(\mathrm{F}_{20-14}\right)$. Internal surface of the foam exhibits a porous structure with irregular cavities and a reduced number of particles agglomerates. Besides, it is observed that a continuous layer partially covers porous with a fine-grained structure. The EDX analysis revealed a value of $\mathrm{Ca} / \mathrm{P}$ ratio of 1.50 , which is very close to the stoichiometric HA value reported in composite materials with TCP particles after being submitted to SBF essays. In this sense, Yu et al. and Raynaud et al. reported the same behavior by using powders of apatitic calcium phosphate with $\mathrm{Ca} / \mathrm{P}$ ratios ranging from 1.50 to $1.67[21,56]$. HA growing could be attributed to the higher diffusion rate of calcium species relative to that of phosphate anions inside the polymeric matrix, which leads to a higher release of calcium from the surface. Altogether, this induces a rapid formation of a thin HA layer owing to the large surface area over which it is distributed. The HA growth is quenched whenever the content of $\mathrm{PO}_{4}{ }^{3-}$ in the solution approaches zero [21]. Ramezani et al. reported that the rapid exchange of $\mathrm{Ca}^{2+}$ and $\mathrm{Mg}^{2+}$ ions with $\mathrm{H}^{+}$or $\mathrm{H}_{3} \mathrm{O}^{+}$from SBF could increase the hydroxyl concentration of the solution. This change led to the superficial modification of the foam, which caused the nucleation of HA. Then, the migration of $\mathrm{PO}_{4}{ }^{3-}, \mathrm{Ca}^{2+}$ and $\mathrm{OH}^{-}$ions from the surrounding fluid to the surface of the foam accelerate the nucleation and precipitation of an HA layer [13]. 


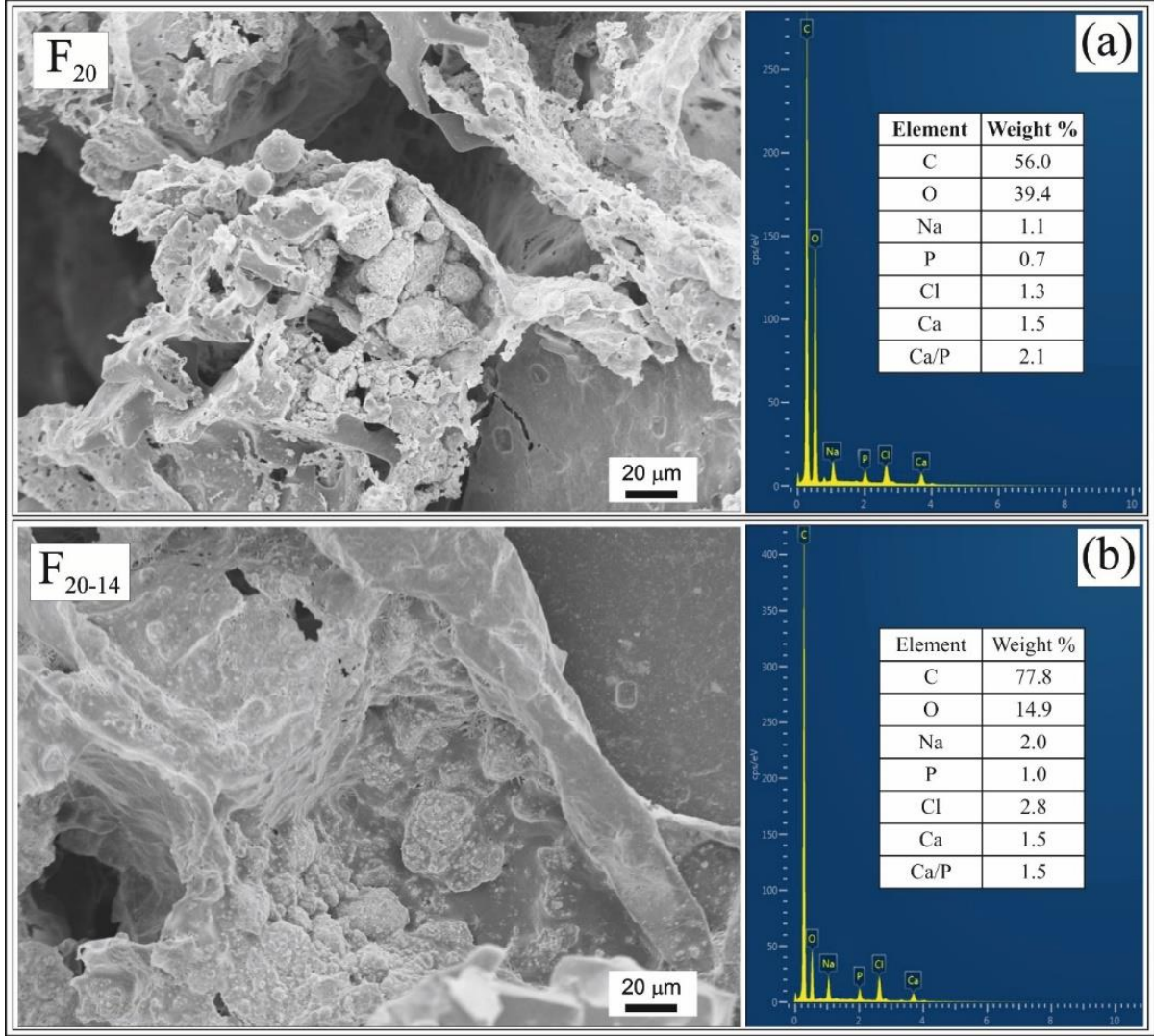

Figure 9. SEM micrographs (1000x) and EDX spectrum of porous PLA foams with $20 \%$ wt filler (a) before immersion in $\operatorname{SBF}\left(\mathrm{F}_{20}\right)$; (b) after immersion in $\operatorname{SBF}\left(\mathrm{F}_{20-14}\right)$.

\section{Conclusions}

PLA porous PLA scaffolds with 10, 15, and $20 \%$ wt of TCP filler were obtained by dissolution-leaching technic. Samples were soaked in SBF in order to confirm the ability of HA formation on the surface of foams, which is a measure of the bioactivity of the material. According to chemical and morphological characterization, by FTIR-ATR, new absorption bands corresponding to HA were detected; and by XRD, typical new patterns associated with an HA-rich phase were found. Porosity values of PLA/TCP foams were $\sim 1.3$ times higher when compared to PLA foam. Regarding mechanical properties, all samples exhibit the compression regions commonly observed for "cellular structures" or porous structures in the stress-strain curves. In addition, upon release of the applied load, the decompression path gives rise to a hysteresis loop. An increasing tendency on elastic Young's modulus values is observed at higher TCP concentration compared to samples unfilled at dry and wet conditions. Besides, the thermal analysis showed that porous foams exhibited lower loss weight values after SBF immersion compared to samples before immersion. These results suggest the transformation of TCP into HA by a dissolution-precipitation mechanism. Finally, by SEM-EDX analysis, it was possible to detect the presence of $\mathrm{HA}$ on the foams' surface by obtaining $\mathrm{Ca} / \mathrm{P}$ values near the stoichiometric HA values found in natural hard tissues.

\section{Funding}

This research was funded by the FONDO PARA LA INVESTIGACIÓN CIENTÍFICA Y TECNOLÓGICA (FONCyT, Argentina), grant number PICT-2016-0181; and the UNIVERSIDAD NACIONAL DE CUYO (UNCuyo, Argentina), grant number SIIP 06/L030B and SeCTyP PROJOVIN 010/2020. 


\section{Acknowledgments}

Authors wish to thank to the Consejo Nacional de Investigaciones Científicas y Técnicas (CONICET, Argentina), the Fondo para la Investigación Científica y Tecnológica (FONCyT, Argentina) and the Universidad Nacional de Cuyo (UNCuyo, Argentina), for the financial support given to perform this research.

\section{Conflicts of Interest}

The authors declare no conflict of interest.

\section{References}

1. Sartore, L.; Inverardi, N.; Pandini, S.; Bignotti, F.; Chiellini, F. PLA/PCL-based foams as scaffolds for tissue $\begin{array}{lllll}\text { engineering } \quad \text { applications. } & \text { Mater. } & \text { Today-Proc. } & \text { 2019, } & \text { 4, }\end{array}$ https://doi.org/10.1016/j.matpr.2018.11.103.

2. Singh, G.; Singh, R.P.; Jolly, S.S. Customized hydroxyapatites for bone-tissue engineering and drug delivery applications: a review. J. Sol-Gel Sci. Technol. 2020, 94, 505-530, https://doi.org/10.1007/s10971-02005222-1.

3. Wang, L.; Wang, D.; Zhou, Y.; Zhang, Y.; Li, Q.; Shen, C. Fabrication of open-porous PCL/PLA tissue engineering scaffolds and the relationship of foaming process, morphology, and mechanical behavior. Polym. Advan. Technol. 2019, 30, 2539-2548, https://doi.org/10.1002/pat.4701.

4. Hou, J.; Jiang, J.; Guo, H.; Guo, X.; Wang, X.; Shen, Y.; Li, Q. Fabrication of fibrillated and interconnected porous poly ( $\varepsilon$-caprolactone) vascular tissue engineering scaffolds by microcellular foaming and polymer leaching. RSC Adv. 2020, 17, 10055-10066, https://doi.org/10.1039/D0RA00956C.

5. Capuana, E.; Lopresti, F.; Carfî Pavia, F.; Brucato, V.; La Carrubba, V. Solution-Based Processing for Scaffold Fabrication in Tissue Engineering Applications: A Brief Review. Polymers 2021, 13, 2041, https://doi.org/10.3390/polym13132041.

6. Park, S.; Kim, J.E.; Han, J.; Jeong, S.; Lim, J.W.; Lee, M.C.; Son, H.; Kim, H.B.; Choung, Y.H.; Seonwoo, H.; Chung, J.H.; Jang, K.J. 3D-printed poly(e-caprolactone)/hydroxyapatite scaffolds modified with alkaline hydrolysis enhance osteogenesis in vitro. Polymers 2021, 13, 257, https://doi.org/10.3390/polym13020257.

7. Hoş, A.; Tunç, K.; Olgun, U. Antibacterial nano biocomposite poly ( $\varepsilon$-caprolactone) films with nano Aghydroxyapatite filler particles. Compos. Interface 2020, 27, 479-493, https://doi.org/10.1080/09276440.2019.1655315.

8. Demina, V.A.; Krasheninnikov, S.V.; Buzin, A.I.; Kamyshinsky, R.A.; Sadovskaya, N.V.; Goncharov, E.N.; Zhukova, N.A.; Khvostov, M.V.; Pavlova, A.V.; Tolstikova, T.G.; Sedush, N.G.; Chvalun, S.N. Biodegradable poly (1-lactide)/calcium phosphate composites with improved properties for orthopedics: effect of filler and polymer crystallinity. Mat. Sci. Eng. C. 2020, 112, 110813, https://doi.org/10.1016/j.msec.2020.110813.

9. Bakhsheshi-Rad, H.R.; Hamzah, E.; Shuang, C.P.; Berto, F. Preparation of poly (e-caprolactone)hydroxyapatite composite coating for improvement of corrosion performance of biodegradable magnesium. Mat. Design Process. Comm. 2020, 2, e170, https://doi.org/10.1002/mdp2.170.

10. Sungsee, P.; Tanrattanakul, V. Biocomposite foams from poly(lactic acid) and rubber wood sawdust: mechanical properties, cytotoxicity, and in vitro degradation. J. Appl. Polym. Sci. 2019, 136, 48259, https://doi.org/10.1002/app.48259.

11. Mondal, S.; Nguyen, T.P.; Hoang, G.; Manivasagan, P.; Kim, M.H.; Nam, S.Y.; Oh, J. Hydroxyapatite nano bioceramics optimized 3D printed poly lactic acid scaffold for bone tissue engineering application. Ceram. Int. 2020, 46, 3443-3455, https://doi.org/10.1016/j.ceramint.2019.10.057.

12. Shah Mohammadi, M.; Rezabeigi, E.; Bertram, J.; Marelli, B.; Gendron, R.; Nazhat, S.N.; Bureau, M.N. Poly(d, 1-lactic acid) composite foams containing phosphate glass particles produced via solid-state foaming using $\mathrm{CO}_{2}$ for bone tissue engineering applications. Polymers. 2020, 12, 231-246, https://doi.org/10.3390/polym12010231.

13. Ramezani, S.; Emadi, R.; Kharaziha, M.; Tavangarian, F. Synthesis, characterization and in vitro behavior of nanostructured diopside/biphasic calcium phosphate scaffolds. Mater. Chem. Phys. 2017, 186, 415-425, https://doi.org/10.1016/j.matchemphys.2016.11.013. 
14. Ngo, H.X.; Dong, Q.N.; Bai, Y.; Sha, J.; Ishizuka, S.; Okui, T.; Sukegawa, S.; Kanno, T. Bone regeneration capacity of newly developed uncalcined/unsintered hydroxyapatite and poly-l-lactide-co-glycolide sheet in maxillofacial surgery: An in vivo study. Nanomaterials. 2021, 11, 22, https://doi.org/10.3390/nano11010022.

15. Nevado, P.; Lopera, A.; Bezzon, V.; Fulla, M.R.; Palacio, J.; Zaghete, M.A.; Biasotto, G.; Montoya, A.; Rivera, J.; Robledo, S.M.; Estupiñan, H.; Paucar, C.; Garcia, C. Preparation and in vitro evaluation of PLA/biphasic calcium phosphate filaments used for fused deposition modelling of scaffolds. Mat. Sci. Eng. C. 2020, 114, 111013, https://doi.org/10.1016/j.msec.2020.111013.

16. Zhao, N.; Lv, Z.; Ma, J.; Zhu, C.; Li, Q. Fabrication of hydrophilic small diameter vascular foam scaffolds of poly(E-caprolactone)/polylactic blend by sodium hydroxide solution. Eur. Polym. J. 2019, 110, 31-40, https://doi.org/10.1016/j.eurpolymj.2018.11.011.

17. Zia, I.; Jolly, R.; Mirza, S.; Umar, M. S.; Owais, M.; Shakir, M. Hydroxyapatite Nanoparticles Fortified Xanthan Gum-Chitosan Based Polyelectrolyte Complex Scaffolds for Supporting the Osteo-Friendly Environment. ACS Appl. Bio Mater. 2020, 3, 7133-7146, https://doi.org/10.1021/acsabm.0c00948.

18. Kołodziejska, B.; Kaflak, A.; Kolmas, J. Biologically inspired collagen/apatite composite biomaterials for potential use in bone tissue regeneration-a review. Materials. 2020, 13, 1748, https://doi.org/10.3390/ma13071748.

19. Loher, S.; Reboul, V.; Brunner, T.J.; Simonet, M.; Dora, C.; Neuenschwander, P.; Stark, W.J. Improved degradation and bioactivity of amorphous aerosol derived tricalcium phosphate nanoparticles in poly(lactideco-glycolide). Nanotechnology. 2006, 17, 2054-2061, https://doi.org/10.1088/0957-4484/17/8/044.

20. Dorozhkin, S.V. Bioceramics of calcium orthophosphates. Biomaterials. 2010, 31, 1465-1485, https://doi.org/10.1016/j.biomaterials.2009.11.050.

21. Yu, Y.; Mathew, R.; Edén, M. Quantitative composition-bioactivity relationships of phosphosilicate glasses: bearings from the phosphorus content and network polymerization. J. Non-Cryst. Solids 2018, 502, 106-117, https://doi.org/10.1016/j.jnoncrysol.2018.07.060.

22. Behera, K.; Sivanjineyulu, V.; Chang, Y.H.; Chiu, F.C. Thermal properties, phase morphology and stability of biodegradable PLA/PBSL/HAp composites. Polym. Degrad. Stabil. 2018, 154, 248-260, https://doi.org/10.1016/j.polymdegradstab.2018.06.010.

23. Mofokeng, J.P.; Luyt, A.S.; Tábi, T.; Kovács, J. Comparison of injection moulded, Natural fibre-reinforced composites with PP and PLA as matrices. J. Thermoplast. Compos. 2012, 25, 927-948, https://doi.org/10.1177\%2F0892705711423291.

24. Fehri, S.; Cinelli, P.; Coltelli, M.B.; Anguillesi, I.; Lazzeri, A. Thermal properties of plasticized poly(lactic acid) (PLA) containing nucleating agent. Int. J. Chem. Eng. Appl. 2016, 7, 85-88, https://doi.org/10.7763/IJCEA.2016.V7.548.

25. Spiridon, I.; Tanase, C.E. Design, characterization and preliminary biological evaluation of new lignin-PLA biocomposites. Int. J. Biol. Macromol. 2018, 114, 855-863, https://doi.org/10.1016/j.ijbiomac.2018.03.140.

26. Grémare, A.; Guduric, V.; Bareille, R.; Heroguez, V.; Latour, S.; L'heureux, N.; Fricain, J.C.; Catros, S.; Le Nihouannen, D. Characterization of printed PLA scaffolds for bone tissue engineering. J. Biomed. Mater. Res. A. 2018, 106, 887-894, https://doi.org/10.1002/jbm.a.36289.

27. Gregor, A.; Filová, E.; Novák, M.; Kronek, J.; Chlup, H.; Buzgo, M.; Blahnová, V.; Lukášová, V.; Bartoš, M.; Nečas, A.; Hošek, J. Designing of PLA scaffolds for bone tissue replacement fabricated by ordinary commercial 3D printer. J. Biol. Eng. 2017, 11, 31-51, https://doi.org/10.1186/s13036-017-0074-3.

28. Gao, Y.; Shao, W.; Qian, W.; He, J.; Zhou, Y.; Qi, K.; Wang, L.; Cui, S.; Wang, R. Biomineralized poly(1lactic-co-glycolic acid)-tussah silk fibroin nanofiber fabric with hierarchical architecture as a scaffold for bone tissue engineering. Mater. Sci. Eng. C. 2018, 84, 195-207, https://doi.org/10.1016/j.msec.2017.11.047.

29. Chen, C.C.; Lee, S.Y.; Teng, N.C.; Hu, H.T.; Huang, P.C.; Yang, J.C. In vitro and in vivo studies of hydrophilic electrospun PLA95/ $\beta$-TCP membranes for guided tissue regeneration (GTR) applications. Nanomaterials. 2019, 9, 599-610, https://doi.org/10.3390/nano9040599.

30. Kokubo, T.; Takadama, H. How useful is SBF in predicting in vivo bone bioactivity? Biomaterials. 2006, 27, 2907-2915, https://doi.org/10.1016/j.biomaterials.2006.01.017.

31. Ninago, M.D.; Ciolino, A.E.; Villar, M.A. Improvement in poly(ع-caprolactone) bio-activity. Structural characterization and in vitro assessment. Int. J. Polym. Mater. Po. 2020, 69, 201-210, https://doi.org/10.1080/00914037.2018.1552864.

32. Redondo, F.L.; Quiroga, G.A.R.; de Freitas, A.G.O.; Villar, M.A.; Ninago, M.D.; Ciolino, A.E. Composite coatings based on linear and branched block copolymers for hydroxyapatite deposition in simulated bodyfluid. Polym-Plast. Technol. 2020, 59, 985-997, https://doi.org/10.1080/25740881.2020.1719138. 
33. Cui, Z.; Nelson, B.; Peng, Y.; Li, K.; Pilla, S.; Li, W.J.; Turng, L.S.; Shen, C. Fabrication and characterization

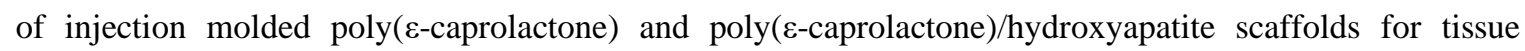
engineering. Mat. Sci. Eng. C. 2012, 32, 1674-1681, https://doi.org/10.1016/j.msec.2012.04.064.

34. Roohani-Esfahani, S.I.; Lu, Z.F.; Li, J.J.; Ellis-Behnke, R.; Kaplan, D.L.; Zreiqat, H. Effect of self-assembled nanofibrous silk/polycaprolactone layer on the osteoconductivity and mechanical properties of biphasic calcium phosphate scaffolds. Acta Biomater. 2012, 8, 302-312, https://doi.org/10.1016/j.actbio.2011.10.009.

35. Chaiwong, C.; Rachtanapun, P.; Wongchaiya, P.; Auras, R.; Boonyawan, D. Effect of plasma treatment on hydrophobicity and barrier property of polylactic acid. Surf. Coat. Tech. 2010, 204, 2933-2939, https://doi.org/10.1016/j.surfcoat.2010.02.048.

36. Peña, J.; Vallet-Regí, M. Hydroxyapatite, tricalcium phosphate and biphasic materials prepared by a liquid mix technique. J. Eur. Ceram. Soc. 2003, 23, 1687-1696, https://doi.org/10.1016/S0955-2219(02)00369-2.

37. Park, C.H.; Kim, E.K.; Tijing, L.D.; Amarjargal, A.; Pant, H.R.; Kim, C.S.; Shon, H.K. Preparation and characterization of LA/PCL composite fibers containing beta tricalcium phosphate ( $\beta$-TCP) particles. Ceram. Int. 2014, 40, 5049-5054, https://doi.org/10.1016/j.ceramint.2013.10.016.

38. Szurkowska, K.; Szeleszczuk, Ł.; Kolmas, J. Effects of Synthesis Conditions on the Formation of SiSubstituted Alpha Tricalcium Phosphates. Int. J. Mol. Sci. 2020, 21, 9164, https://doi.org/10.3390/ijms21239164.

39. Mohandes, F.; Salavati-Niasari, M. In vitro comparative study of pure hydroxyapatite nanorods and novel polyethylene glycol/graphene oxide/hydroxyapatite nanocomposite. J. Nanopart. Res. 2014, 16, 2604-2615, https://doi.org/10.1007/s11051-014-2604-y.

40. Miola, M.; Verné, E.; Ciraldo, F.E.; Cordero-Arias, L.; Boccaccini, A.R. Electrophoretic deposition of chitosan/45S5 bioactive glass composite coatings doped with $\mathrm{Zn}$ and Sr. Front. Bioeng. Biotech. 2015, 3, 159-171, https://doi.org/10.3389/fbioe.2015.00159.

41. Cordero-Arias, L.; Cabanas-Polo, S.; Goudouri, O.M.; Misra, S.K.; Gilabert, J.; Valsami-Jones, E.; Sanchez, E.; Virtanen, S.; Boccaccini, A.R. Electrophoretic deposition of ZnO/alginate and ZnO-bioactive glass/alginate composite coatings for antimicrobial applications. Mat. Sci. Eng. C. 2015, 55, 137-144, https://doi.org/10.1016/j.msec.2015.05.034.

42. Spiridon, I.; Leluk, K.; Resmerita, A.M.; Darie, R.N. Evaluation of PLA-lignin bioplastics properties before and after accelerated weathering. Compos. PartB-Eng. 2015, 69, 342-349, https://doi.org/10.1016/j.compositesb.2014.10.006.

43. Liu, D.; Zhuang, J.; Shuai, C.; Peng, S. Mechanical properties' improvement of a tricalcium phosphate scaffold with poly-l-lactic acid in selective laser sintering. Biofabrication 2013, 5, 025005-025015, https://doi.org/10.1088/1758-5082/5/2/025005.

44. Ginebra, M.P.; Driessens, F.C.M.; Planell, J.A. Effect of the particle size on the micro and nanostructural features of a calcium phosphate cement: a kinetic analysis. Biomaterials 2004, 25, 3453-3462, https://doi.org/10.1016/j.biomaterials.2003.10.049.

45. Nagase, M.; Chen, R.B.; Asada, Y.; Nakajima, T. Radiographic and microscopic evaluation of subperiosteally implanted blocks of hydrated and hardened $\alpha$-tricalcium phosphate in rabbits. J. Oral. Maxil. Surg. 1989, 47, 582-586, https://doi.org/10.1016/S0278-2391(89)80073-4.

46. Sultana, N. Mechanical and biological properties of scaffold materials. In Functional 3D tissue engineering scaffolds; Deng, Y., Kuiper, J.; Eds.; Malaysia, 2018; 1-21, https://doi.org/10.1016/B978-0-08-1009796.00001-X.

47. Stampella, A.; Papi, A.; Rizzitelli, G.; Costantini, M.; Colosi, C.; Barbetta, A.; Massimi, M.; Devirgiliis, L.C.; Dentini, M. Synthesis and characterization of a novel poly(vinyl alcohol) 3D platform for the evaluation of hepatocytes' response to drug administration. J. Mater. Chem. B. 2013, 1, 3083-3098, https://doi.org/10.1039/C3TB20432D.

48. Wu, D.; Spanou, A.; Diez-Escudero, A.; Persson, C. 3D-printed PLA/HA composite structures as synthetic trabecular bone: a feasibility study using fused deposition modeling. J. Mech. Behav. Biomed. 2020, 103, 103608-103617, https://doi.org/10.1016/j.jmbbm.2019.103608.

49. Mohandes, F.; Salavati-Niasari, M. Freeze-drying synthesis, characterization and in vitro bioactivity of chitosan/graphene oxide/hydroxyapatite nanocomposite. RSC. Adv. 2014, 4, 25993-26001, https://doi.org/10.1039/C4RA03534H.

50. Roether, J.A.; Boccaccini, A.R.; Hench, L.L.; Maquet, V.; Gautier, S.; Jérome, R. Development and in vitro characterisation of novel bioresorbable and bioactive composite materials based on polylactide foams and 
bioglass $^{\circledR}$ for tissue engineering applications. Biomaterials 2002, 23, 3871-3878, https://doi.org/10.1016/S0142-9612(02)00131-X.

51. Suchanek, W.; Yoshimura, M. Processing and properties of hydroxyapatite-based biomaterials for use as hard tissue replacement implants. J. Mater. Res. 1998, 13, 94-117. https://doi.org/10.1557/JMR.1998.0015.

52. Zhang, K.; Wang, Y.; Hillmyer, M.A.; Francis, L.F. Processing and properties of porous poly(Llactide)/bioactive glass composites. Biomaterials 2004, 25, 2489-2500, https://doi.org/10.1016/j.biomaterials.2003.09.033.

53. Maeda, H.; Maquet, V.; Kasuga, T.; Chen, Q.Z.; Roether, J.A.; Boccaccini, A.R. Vaterite deposition on biodegradable polymer foam scaffolds for inducing bone-like hydroxycarbonate apatite coatings. J. Mater. Sci. Mater. Med. 2007, 18, 2269-2273, https://doi.org/10.1007/s10856-007-3108-4.

54. Haaparanta, A.M.; Haimi, S.; Ellä, V.; Hopper, N.; Miettinen, S.; Suuronen, R.; Kellomäki, M. Porous polylactide/ $\beta$-tricalcium phosphate composite scaffolds for tissue engineering applications. J. Tissue Eng. Regen. M. 2010, 4, 366-373, https://doi.org/10.1002/term.249.

55. Somrani, S.; Rey, C.; Jemal, M. Thermal evolution of amorphous tricalcium phosphate. J. Mater. Chem. 2003, 13, 888-892, https://doi.org/10.1039/B210900J.

56. Raynaud, S.; Champion, E.; Bernache-Assollant, D.; Thomas, P. Calcium phosphate apatites with variable $\mathrm{Ca} / \mathrm{P}$ atomic ratio I. Synthesis, characterisation and thermal stability of powders. Biomaterials 2002, 23, 1065-1072, https://doi.org/10.1016/S0142-9612(01)00218-6. 